\title{
Hsp70 Induction and Anticancer Activity of U-133, the Acetylated Trisglucosydic Derivative of Echinochrome
}

\author{
Ekaterina A Yurchenko ${ }^{1 *}$, Ekaterina S Menchinskaya ${ }^{2}$, Sergei G Polonik ${ }^{1}$, Irina G Agafonova ${ }^{1}$, Irina V Guzhova ${ }^{2}$, Boris A Margulis ${ }^{1}$ and \\ Dmitry L Aminin ${ }^{1}$ \\ ${ }^{1}$ Laboratory of bioassays and mechanism of action of biologically active compounds, G.B. Elyakov Pacific Institute of Bioorganic Chemistry, Far Eastern Branch of the \\ Russian Academy of Sciences, 690022, pr. 100 let Vladivostoku 159, Vladivostok, Russia \\ ${ }^{2}$ Laboratory of protective mechanisms of cell, Institute of Cytology, Russian Academy of Sciences, 194064, Tichoretskii pr. 4, St.-Petersburg, Russia
}

\begin{abstract}
Acetylated trisglucosydic derivative of 2,3,5,6,8-pentahydroxy-7-ethyl-1,4-naphthoqinone (natural sea urchin pigment echinochrome), compound U-133, was synthesized. The effect of U-133 upon mouse Ehrlich ascitic carcinoma (EAC) cells in vitro and its antitumor activity in vivo was investigated. The synthesized U-133 did not display the pronounced cytotoxicity against EAC cells in the concentrations up to $80 \mu \mathrm{M}$. In non-cytotoxic concentration of $5 \mu \mathrm{M} \mathrm{U}-133$ significantly induced Hsp70 expression in cancer cells and enhanced cell-mediated cytotoxicity of mouse splenocytes against EAC cells. The administration of U-133 in dosage of $100 \mathrm{mg} / \mathrm{kg}$ in carcinoma bearing mice resulted in significant inhibition of tumor growth and increase in mouse lifespan.
\end{abstract}

Keywords: Hsp70 expression; Ehrlich carcinoma; Anticancer activity; Tumor growth inhibition, 1,4-naphtohinones; U-133

\section{Introduction}

A large family of naturally occurring quinones is a promising source for the searching of new substances with potent biological activity [1]. In particular, a number of natural naphthazarins (5,8-dihydroxy-1,4naphthoquinones) has been isolated and studied for their antibacterial [2], cytotoxic and antitumor [3-5], nematicidal [6], and antiinflammatory properties [7]. Hydroxylated 1,4-nahthoqinones are the natural pigments of sea urchins [8]. One of them 2,3,5,6,8-pentahydroxy7-ethyl-1,4-naphthoqinone (echinochrome A) 1 isolated from sea urchin Scaphechinus mirabilis, is the main component of Russian drug Histochrome $^{\circledast}$ [9], which is widely used for the treatment of burns and traumas of eyes, ischemia, myocardial infarction and hemorrhagic stroke. It is suggested that the mentioned biological activities of this drug are based on its pronounced antioxidant properties [10]. Recently it was shown that echinochrome A 1 also increases mitochondrial contents in rat cardio myoblasts and up-regulates mitochondrial biogenesis regulatory genes such as PGC-1a, TFAM, TFB2M, nuclear respiratory factor NRF-1, and some others [11].

For investigation of biological activity of different echinochrome A derivatives the some glicosilated compounds were synthesized early. It was established that trisglucoside U-133 significantly increased Hsp70 expression in human erythroleukemia K562 cells [12]. The analysis of quantity and activity of cellular chaperones during the human leukemia U-937 cell response to heat stress or to the U-133 application showed that both factors caused the accumulation of chaperones with similar kinetics [13].

Heat shock proteins (HSPs), specifically the chaperone Hsp70, comprise molecular systems that are necessary for all living cells for normal functioning and protection from adverse factors. Within the last years evidence has been accumulating that HSPs can play an important role in the antitumour immune response. Members of the Hsp70 group have been found to be expressed on the cell surface of certain tumor cells [14-16], where they can act as immunogenic determinants for effector cells $[17,18]$. It was observed that Hsp70 can translocate on cancer cell surface or in extracellular area and present tumor antigens to antigen-presenting cells that results in activation of both cellular and humoral immune systems $[19,20]$ and increasing in Hsp70 expression on cancer cells surface results in elevation of cancer cell sensitivity to NK-cells action $[21,22]$.
It was found that a number of chemotherapeutical drugs and drug candidates are able to modulate Hsp70 expression both in cytosol and at the membrane besides their antitumor effect. For instance, cytostatic drugs, vincristine and paclitaxel, which induce tubulin aggregation in cancer cells, at sub-lethal concentrations caused increasing in cytosol and membrane-bound Hsp70 content in K562 cells [23]. Drug candidate N'1,N'3-dimethyl-N'1,N'3-di(phenylcarbonothioyl)malonohydrazide (STA-4783 or elesclomol) demonstrated Hsp70 induction and anticancer activity against a wide range of tumor cell lines including a number of MDR tumor cell lines that was immune to taxol [24].

However, the influence of U-133 upon cell surface Hsp70 expression in tumor cells and cancer cell sensitivity to cytotoxic action of immune cells was not examined such as anticancer effect of U-133. The purpose of present study is to investigate of U-133 influence on Hsp70 expression level in mouse Ehrlich ascitic carcinoma cells and its anti-tumor effects in vitro and in vivo.

\section{Materials and Methods}

\section{Compound}

Echinochrome 1 was isolated from the sea urchin Scaphechinus mirabilis [25]. In order to obtain water-soluble naphthoquinone derivatives echinochrome 1 was condensed with tert-butyl-1,2orthoester of D-glucose 2 in dry chlorobenzene under reflux and converted in 2,3,7-tris(tetra-O-acetyl- $\beta$-D-glucopyranosyl)-6-ethyl5,8-dihydroxy-1,4-naphthoquinone (U-133) 3 with $66 \%$ yield. The acetylderivative U-133 3 was deacetylated by treatment with sodium methoxide/methanole solution in polar trisglucoside U-137 4 (Scheme

*Corresponding author: Dr. Ekaterina Yurchenko, Laboratory of bioassays and mechanism of action of biologically active compounds, G.B. Elyakov Pacific Institute of Bioorganic Chemistry, Far Eastern Branch of the Russian Academy of Sciences, pr. 100-let Vladivostoku 159, 690022, Vladivostok, Russia, Tel: +7-423233-9932; Fax: +7-423-233-4050; E-mail: dminae@mail.ru

Received May 04, 2015; Accepted June 22, 2015; Published June 24, 2015

Citation: Yurchenko EA, Menchinskaya ES, Polonik SG, Agafonova IG Guzhova IV, et al. (2015) Hsp70 Induction and Anticancer Activity of U-133, the Acetylated Trisglucosydic Derivative of Echinochrome. Med chem 5: 263-271. doi: 10.4172/2161-0444.1000274

Copyright: @ 2015 Yurchenko EA, et al. This is an open-access article distributed under the terms of the Creative Commons Attribution License, which permits unrestricted use, distribution, and reproduction in any medium, provided the original author and source are credited. 
1). Water soluble echinochrome trisglucoside U-137 4 was unstable and readily decompose in complex mixture of reaction products [26], therefore we work with stable acetylderivative U-133 3. The chemical structure of compound 3 (U-133) is shown on Figure 1a. Stock solutions $(2 \mathrm{mM})$ of 3 were prepared using dimethylsulfoxide as the solvent, and were stored in darkness at $-18^{\circ} \mathrm{C}$. The final concentration of DMSO in cell culture did not exceed $1 \%$.

\section{Animals}

CD-1 and $\mathrm{BALB} / \mathrm{c}$ mice weighing 18-20 g were purchased from the nursery Stolbovaya of Scientific Centre of Biomedical Technologies of Russian Academy of Sciences (Moscow, Russia) and kept at the animal facility under standard conditions. CD-1 mice were used for inoculation of Ehrlich carcinoma cells in in vitro and in vivo experiments. BALB/c mice were used for peritoneal macrophage isolation. All experiments were conducted in compliance with all rules and international recommendations of the European Convention for the Protection of Vertebrate Animals used for experimental studies.

\section{Cell cultures}

Ehrlich carcinoma cells: The museum tetraploid strain of mouse Ehrlich carcinoma was provided by the N.N. Blokhin Russian Oncology Center (Moscow, Russia). The cells of Ehrlich carcinoma were injected into the peritoneal cavity of 18-20 g albino CD-1 mice (male and female). Cells for experimentation were collected 7 days after inoculation. The mice were killed by pervisceral dislocation and the ascitic fluid containing tumor cells was collected with a syringe. The cells were washed two times by centrifugation in phosphate buffered saline (PBS, pH 7.4) followed by re-suspension in RPMI-1640 cultural medium containing gentamicine $50 \mu \mathrm{g} / \mathrm{ml}$ (BioloT, St.-Petersburg, Russia) without serum. The cell number and viability were counted with a hemocytometer and trypan blue staining procedure. The final cell concentration in the medium usually was $1-2 \times 10^{6} \mathrm{cell} / \mathrm{ml}$.

HeLa-luc cells: Stable Hsp70.1 promoter-luciferase reporter HeLa cell line (HeLa-luc) were cultured in DMEM medium supplemented with $10 \%$ fetal bovin serum (BioloT, St.-Petersburg, Russia), $2 \mathrm{mM}$ L-glutamine, penicillin $(5000 \mu \mathrm{m} / \mathrm{ml})$ and streptomycin $(5 \mathrm{mg} / \mathrm{ml})$. The selection of resistant cells was done using genicitine G-418 $(500 \mu \mathrm{g} / \mathrm{ml}$, Sigma-Aldrich, St. Louis, USA).

\section{Cell viability}

Cell viability assay was evaluated according to standard MTT method [27]. Briefly, EAC cells $\left(1 \times 10^{6}\right.$ cells $\left./ \mathrm{ml}\right)$ were seeded in a 96well microplate and incubated with various concentrations of U-133 for $24 \mathrm{~h}$. Subsequently, the culture medium was replaced with $100 \mu \mathrm{l}$ fresh medium. After that $10 \mu \mathrm{l}$ of MTT (Sigma-Aldrich, USA) stock solution $(5 \mathrm{mg} / \mathrm{ml})$ was added to each well and the microplate was

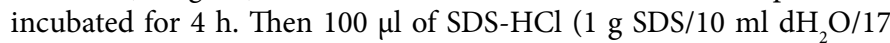
$\mu \mathrm{l} 6 \mathrm{~N} \mathrm{HCl})$ was added to each well followed by incubation for 18 h. Absorbance of converted dye, formazan, was measured using a Multiskan FC microplate photometer (Thermo Scientific, USA) at 570 $\mathrm{nm}$ with background subtraction at $630-690 \mathrm{~nm}$. Cytotoxic activity of compound was expressed as $\mathrm{EC}_{50}$.

\section{Luciferase assay}

Luciferase assay was carried out according to the published method

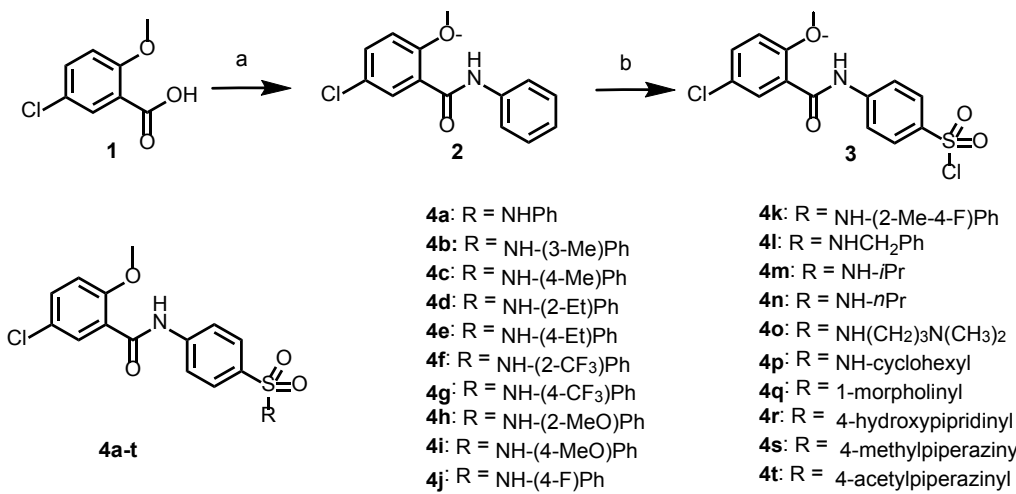

Scheme 1: Synthesis of trisglucoside derivatives of echinochrome.<smiles>CCOC1=C(OCC)C(=O)c2c(O)c(OC(C)(C)C)c(OC(C)C)c(O)c2C1=O</smiles>

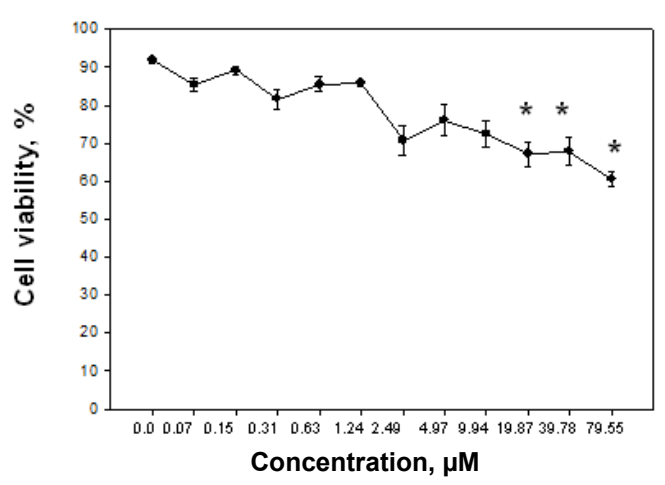

Figure 1: Chemical structure of U-133 (a) Cytotoxic activity of U-133 against EAC cells for $24 \mathrm{~h}(\mathbf{b}){ }^{*} \mathrm{p}<0.05$ compared with control cells. 
[28]. For experiments with the Hsp70.1 promoter-luciferase reporter stable HeLa cell line, cells were plated to $1 \times 10^{6}$ cells/well in 24 well plates and incubated at $37^{\circ} \mathrm{C}$ with $5 \% \mathrm{CO}_{2}$ for $24 \mathrm{~h}$. The solutions of $\mathrm{U}-133$ at different concentrations were added in wells on the next day and plates were incubated additionally for indicated time. Then the cells were rinsed by cold PBS and lysed in buffer ( $1 \%$ Triton X-100, $25 \mathrm{mM}$ glycine, $15 \mathrm{mM} \mathrm{MgSO}, 4 \mathrm{mM}$ EGTA) for $30 \mathrm{~min}$ at $-80^{\circ} \mathrm{C}$. After defrosting the aliquots of cell lysates were transferred in white 96well plates and luciferase assays were performed using the Bright-Glo assay system (Promega, Fitchburg, USA) according to manufacturer's instructions. Luminescence intensity was measured using Luminoskan Ascent microplate photometer (Thermo Electron Corporation, USA) and expressed as arbitrary units (a.u.).

\section{Immunoblotting}

The Ehrlich ascites carcinoma cell suspension $\left(2 \times 10^{6} / \mathrm{ml}\right)$ was placed in 6-well plates containing U-133 solution and incubated at $37^{\circ} \mathrm{C}$ and $5 \% \mathrm{CO}_{2}$ for different time. Then cells were collected, washed and used for the sample preparation for electrophoresis. Heat shock treated cells $\left(42^{\circ} \mathrm{C}\right.$ for $30 \mathrm{~min}$ ) were used as positive control.

Proteins were separated using the method of SDS electrophoresis in $10 \%$ polyacrylamide gel. The electrophoretically separated proteins were transferred onto the nitrocellulose membrane Whatman (SigmaAldrich, St. Louis, USA) using a semi-dry transfer apparatus (Helicon, Moscow, Russia). The Hsp70 protein zone was revealed using specific monoclonal antibodies against Hsp70 BRM-22a (Sigma-Aldrich, St. Louis, USA) in dilution of 1:1000 and of secondary antibodies conjugated with horseradish peroxidase in dilution of 1:10000 (SigmaAldrich, St. Louis, USA). The peroxidase reaction was visualized by enhanced chemiluminescence (ECL) method according to instruction of the manufacturer (Sigma-Aldrich, St. Louis, USA) using VersaDoc imaging system (Bio-Rad, USA).

\section{Immunocytochemistry}

For immunocytochemistry staining Ehrlich carcinoma cells were collected, washed with cold PBS and fixed by $100 \%$ methanol during 5 min. After that the cells were incubated with $0.25 \%$ Triton X-100 during $30 \mathrm{~min}$. Then cells were washed twice with PBS and incubated with BRM-22a antibodies against Hsp70 (Sigma-Aldrich, St. Louis, USA) in dilution of 1:1000. Then secondary antibodies conjugated with Mega485 (Sigma-Aldrich, St. Louis, USA) were used in optimal dilution of 1:10000. The secondary fluorescent dye-labeled antibody without use of BRM-22a primary antibody to Hsp70 was used as control to detect non-specific cell staining. Examination of fluorescence intensity in single cells was performed with an LSM 510 META confocal laser scanning microscope (Carl Zeiss, Germany) equipped with an Ar laser with an effective power of $30 \mathrm{~mW}$, using Plan-Neofluar $40 \times 1.3 /$ Oil objective. Confocal images were obtained after excitation at $488 \mathrm{~nm}$ and emission at $522 \mathrm{~nm}$. The intensity of the Ar laser was $5.9 \%$ of maximal power for Mega485 fluorescent probe excitation. These settings were constant for every set of experiments. Image processing was evaluated with Release 3.5 and ZEN 2010 software (Carl Zeiss, Germany). Data were presented as the mean from several separate experiments (at least 200-300 cells were analyzed in each experiment).

\section{Splenocytes cytotoxicity assay}

Effector cells: Splenocytes were isolated from spleens of BALB/c mice by standard procedure, re-suspended at concentration of $1 \times 10^{7}$ cells/ml in RPMI-1640 medium supplemented with $10 \%$ fetal bovine serum.

Target cells: Ehrlich carcinoma cells $\left(1 \times 10^{6}\right.$ cells $\left./ \mathrm{ml}\right)$ were incubated with $10 \mu \mathrm{M} \mathrm{U}-133$ at $37^{\circ} \mathrm{C}$ for $2 \mathrm{~h}$. After that the cells were collected and washed once by centrifugation. Then the cells were resuspended with RPMI-1640 medium containing $1 \mu \mathrm{M}$ calcein-AM (Sigma-Aldrich, St. Louis, USA). After incubation at $37^{\circ} \mathrm{C}$ for $15 \mathrm{~min}$ the cells were washed by centrifugation and re-suspended with RPMI1640 medium contained $10 \%$ fetal bovine serum at concentration of 1 $\times 10^{5} \mathrm{cells} / \mathrm{ml}$.

Cytotoxicity assay was carried out by a calcein-AM release method as described previously $[29,30]$. Cytotoxicity was evaluated in terms of the fluorescence intensity (\%) of calcein released from dead target cells.

\section{Anticancer activity in vivo}

Ascitic Ehrlich carcinoma model: Ehrlich carcinoma cell suspension was inoculated i.p. into CD-1 mice $\left(2 \times 10^{6}\right.$ cells $/$ mouse $)$. $\mathrm{U}-133$ therapy was initiated on the next day after cancer cell inoculation. Compound solution in 20\% DMSO was injected subcutaneously in volume of $200 \mu \mathrm{l}$ at dosage of $100 \mathrm{mg} / \mathrm{kg}$ every two days, six times in all. Control mice received 20\% DMSO solution subcutaneously $(200 \mu \mathrm{l}$ per mouse).

In another type of experiments Ehrlich carcinoma cell suspension $\left(2 \times 10^{6}\right.$ cells $\left./ \mathrm{ml}\right)$ was loaded in Petri dishes containing $1 \mu \mathrm{M}$ U-133 solution and cells were incubated at $37^{\circ} \mathrm{C}$ for $3 \mathrm{~h}$. Then the cells were washed by centrifugation and cell sediment was re-suspended in $1.5 \mathrm{ml}$ PBS and inoculated i.p. into CD-1 mice in volume of $0.2 \mathrm{ml}$ per mouse.

Two groups (control and experimental), 6-10 mice in each group, were used in the experiments.

Solid Ehrlich carcinoma model: The tumor cells were hypodermically inoculated under the left shoulder blade of the mouse, $5 \times 10^{6}$ cells/mouse in $0.5 \mathrm{ml}$ of saline. On the next day after tumor inoculation, mice were treated with U-133.

Two groups, 7 mice in each group, were used in the experiments:

a) Group 1 (control): Animals received 20\% DMSO solution subcutaneously (200 $\mu$ l per mouse).

B) Group 2 (experimental): Animals were subcutaneously administrated with a U-133 solution in $20 \%$ DMSO in volume of $200 \mu \mathrm{l}$ at dosage of $100 \mathrm{mg} / \mathrm{kg}$ every two days, seven times in all.

Dynamics of carcinoma growth and antitumor effect was estimated by tumor growth relative to a control using magnetic resonance tomography (MRT) on a PharmaScan US 70/16 (Bruker, Germany) tomograph. The first scanning was done the week after the tumor inoculation. Each experimental animal was first anestized by a solution of Rometar (Xylazinum, Spofa, Czech Republic) at dosage of $5.5 \mathrm{mg} /$ $\mathrm{kg}$. T2-weighted images in spine-echo (SE) regime along with RARE_8 protocols specially modified for this investigation was used for visualization and identification of changes in tumor size.

The main image has followed the parameters: TR=2579.8 ms; $\mathrm{TE}=44.5 \mathrm{~ms}$; FOV=3-3.5 cm, matrix $-256 \times 256$; thickness of the cross-section $-1.2 \mathrm{~mm}$; a distance between cross-sections $-1.5 \mathrm{~mm}$; the number of cross-sections - 12-16.

Images were analyzed and tumor volumes from two orthogonal sets of multislice-multi-echo images covering the entire tumor were calculated using ParaVision 3.0.1. software facilities (Bruker, Germany). The solid tumor volume $\left(\mathrm{V}_{\Sigma}\right)$ was calculated from the equation:

$$
\mathrm{V}_{\Sigma}=\mathrm{h} \sum_{i=1}^{n} S i
$$


where $\mathrm{h}$ - thickness of slice ( $\mathrm{mm})$; $\mathrm{n}$ : total number of slices; i: running slice number; $\mathrm{S}$ : area of slice $\left(\mathrm{mm}^{2}\right)$.

Survivability of mice was evaluated by observation every day during 40 days. The average life span (ALS) for animals bearing ascitic tumors was determined for control and experimental groups. Increase in the life span (ILS, \%) was determined according to the equation: ILS=(T/C) $\times 100 \%$, where $\mathrm{T}$ and $\mathrm{C}$ are the average life span (days) of animals in the experimental and the control groups, respectively.

\section{Statistical analysis}

Average value, standard error, standard deviation and p-values in all experiments were calculated and plotted on the chart using SigmaPlot 3.02 (Jandel Scientific, USA). Statistical difference was evaluated by $t$-test, and results were considered as statistically significant at $p<0.05$.

\section{Results and Discussion}

\section{Effect of U-133 on EAC cell viability}

To determine the drug concentration range in which the compound is not toxic for cells, its cytotoxic activity was investigated (Figure 1b). The $\mathrm{EC}_{50}$ for U-133 estimated by MTT assay was found to be more than $100 \mu \mathrm{M}$. If the U-133 was applied at maximal concentration of $80 \mu \mathrm{M}$ then only approximately $40 \%$ of EAC cell death was observed after 24 $\mathrm{h}$ of cell incubation with compound. Therefore, all further experiments were executed with $\mathrm{U}-133$ concentration range of $1-10 \mu \mathrm{M}$.

\section{U-133 induces Hsp70 expression in HeLa-luc and EAC cells}

In order to determine whether the compound causes increased expression of heat shock proteins in the EAC cells, two standard approaches were applied: the estimation of chaperone induction in a transgenic cell culture HeLa-luc [28], and evaluation of chaperone expression in EAC cells by immunocytochemistry ECA [12].

U-133 was shown to induce expression of an Hsp70.1 promoter luciferase reporter gene stably integrated into HeLa cells (HeLa-luc cells). The linear dose-response relationship of U-133 effect upon Hsp70 expression in HeLa-luc cells was demonstrated in the range of compound concentrations 1-10 $\mu \mathrm{M}$ (Figure 2a).

U-133 activates the Hsp70 promoter reporter in diverse cell types to levels comparable with that obtained with heat shock $\left(42^{\circ} \mathrm{C}\right.$; data not shown). The induction of Hsp70 expression was observed in the human HeLa-luc and mouse EAC cells (Figures 2 and 3). These results demonstrate that U-133 can activate the Hsp70 expression irrespective of cell type.

It was recorded that the level of Hsp70 expression initiated by U-133 in HeLa-luc cells is time-dependent. Thus, Hsp70 expression level was found to be increased after 2-3 $\mathrm{h}$ of incubation and reached the maximum after $24 \mathrm{~h}$ of incubation (Figure $2 \mathrm{~b}$ ).

The observed dynamic of Hsp70 expression in U-133 treated HeLa-luc cells was similar to that of EAC cells. The accumulation of the amount of the appropriate gene product measured with the aid of Western blotting in the U-133 treated EAC cells was distinctly shown at approximately $3 \mathrm{~h}$ of incubation and significantly increased after $24 \mathrm{~h}$. Typical immunoblots are presented in Figure 2c.
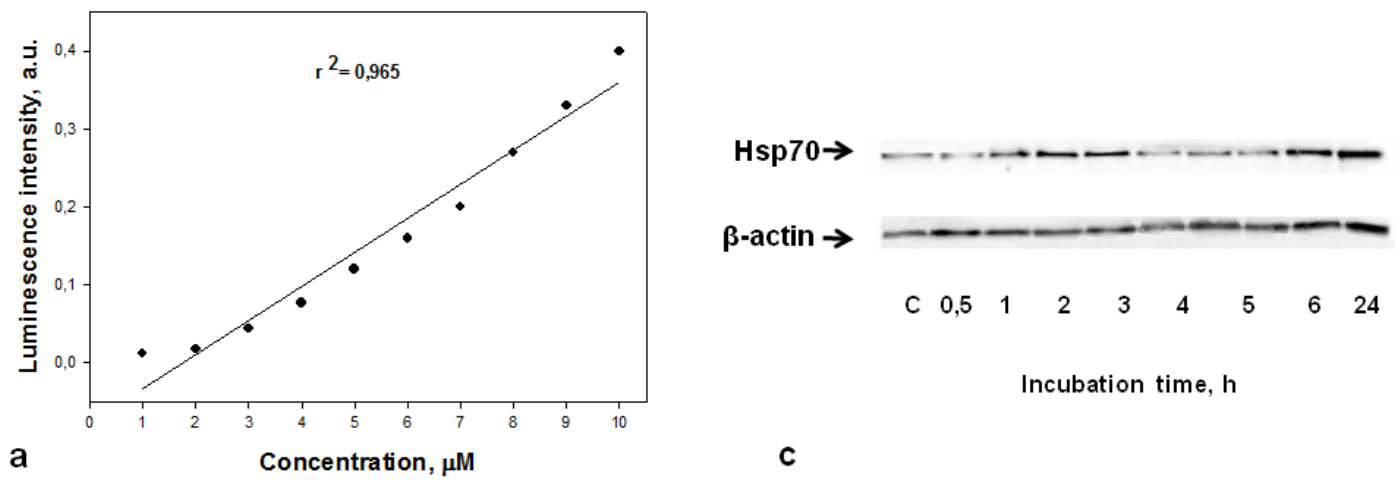

Incubation time, $\mathrm{h}$

c

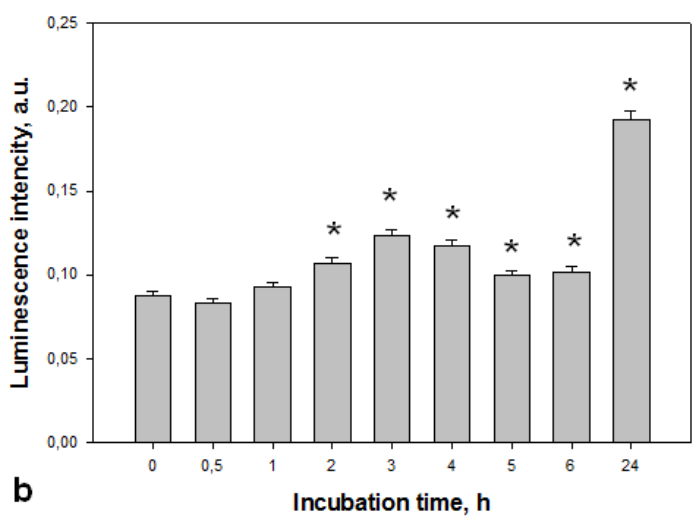

Figure 2: Effect of U-133 on Hsp70 expression in HeLa-luc cells and EAC cells. Dose-dependent curve of the Hsp70 induction in U-133 treated HeLa-luc cells. Incubation time is $18 \mathrm{~h}$ (a) Changes in Hsp70 expression in HeLa-luc cells treated with $10 \mu \mathrm{M} \mathrm{U}-133$ (b) Changes in amounts of Hsp70 in EAC cells after treatment with $5 \mu \mathrm{M} \mathrm{U}-133$ (c) ${ }^{*} \mathrm{p}<0.05$ compared with control cells. 


\section{Treatment with U-133 increases of Hsp70 expression on EAC cell surface}

To study changes in Hsp70 localization in U-133-treated EAC cells we employed confocal microscopy using BRM-22 antibody. The antibody was earlier found to recognize both cytosolic and membranebound forms of the protein [31]. We found that in full agreement with the data on Hsp70 expression the protein amount after the beginning of incubation with U-133 was grown in cytoplasm and the green speckles appeared in a close proximity to a cell surface (Figures $3 \mathrm{a}$ and $3 \mathrm{c}$ ). We measured the whole area of staining with BRM-22 antibody and the data show that Hsp70 expanding throughout a cell developed in a timedependent manner (Figure 3b).

The kinetic curve of the process indicates that an increase in the total amount of the chaperone Hsp70 in the cytoplasm and on the cellular surface started $2 \mathrm{~h}$ after $\mathrm{U}-133$ treatment, and the significant maximum occurred at $24 \mathrm{~h}$.

\section{U-133 increases cell-mediated cytotoxicity of splenocytes against tumor cells}

To ascertain the fact that the incubation of tumor cells with U-133 could increase the cytotoxic properties of lymphocytes, we investigated the cell-mediated cytotoxicity of mouse splenocytes against tumor cells.

It is known that Hsp70 accumulating in cells due to the action of a certain factor and expressing at a cell surface can trigger anti-tumor cytotoxic response elicited by NK cells [23]. Our results show (Figure 4) that 2-hour treatment of EAC cells with U-133 increased their sensitivity to cytotoxic effect of spleenocytes by $20 \%$ at the effector:target cell ratio 100:1.

\section{U-133 exhibits anticancer effect in vivo}

The data of lymphocyte cell-mediated cytotoxity assay in vitro prompted us to analyze the anti-tumor effect of the substance in mouse model of carcinoma. In this study after preliminary treatment with $\mathrm{U}-133$ at $1 \mu \mathrm{M}$ during $3 \mathrm{~h}$ the EAC cells were intraperitoneally (i.p.) injected into the mice, and their survival was then calculated after 40 days of observation in both control and experimental groups of animals. ALS for control group was found to be 14 days in control and 19 days in experimental group, and ILS was calculated to be $26 \%$ (Figure 5).

In another type of experiments the untreated EAC cells were i.p. injected into the mice and then U-133 therapy was applied. It was found that U-133 administrated subcutaneously at a dose of 100 $\mathrm{mg} / \mathrm{kg}$ inhibited the in vivo development of ascites tumors in the early period after tumor inoculation. Approximately $80 \%$ cases of tumor development were not visually detected on the twelfth day in experimental group of animals. In contrast, $100 \%$ of the mice in the control group had developed tumors (Figure 6). However, on the $21^{\text {st }}$ day of development tumors were observed in both groups.

Figure 6a shows the dynamics of the survival of mice with Ehrlich ascites carcinoma in the control group and in the group receiving $\mathrm{U}-133$. On the assumption of these data, ALS of the control group was 16.4 days whereas the group using the drug had a statistically significant $(\mathrm{p}<0.05)$ increase in the life span up to 20.6 days. In this case, the ILS was $25.6 \%$ as compared to control group.

Suggesting that the elevation of viability of mice was due to the inhibition of tumor growth rate in animals injected with U-133 we carried out analysis of cancerous tissues using the method of high

a

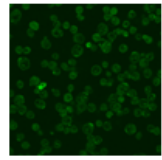

Control

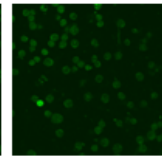

1

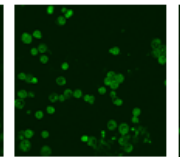

2

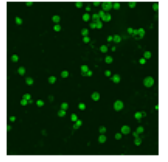

3

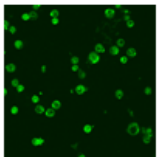

4

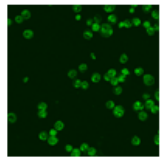

5

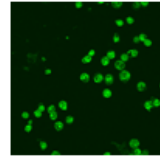

6

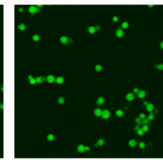

24

Incubation time, $\mathbf{h}$

b

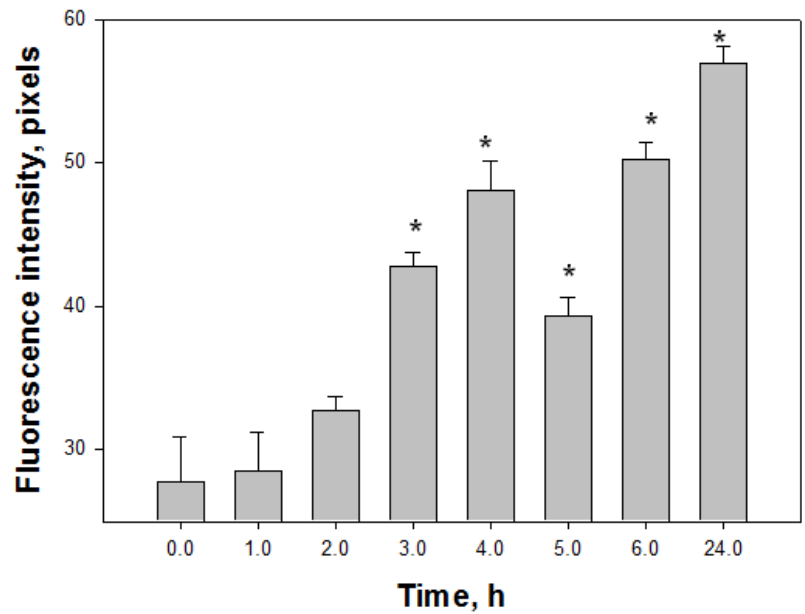

C fluo

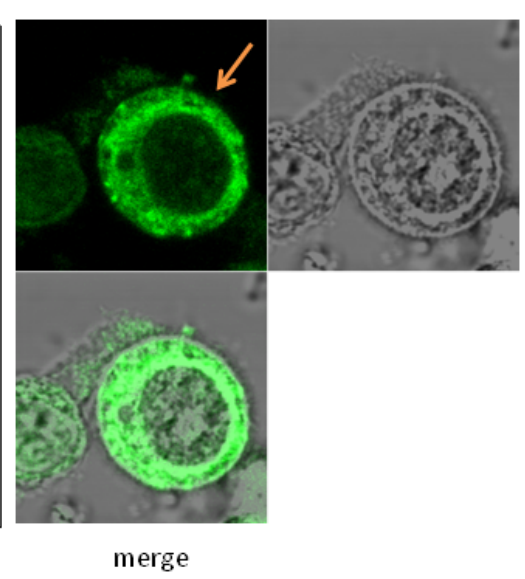

Figure 3: Immunocytochemical visualization of Hsp70 expression changes in the cells using Hsp70-specific BRM-22a antibody in EAC cells treated with $5 \mu \mathrm{M} \mathrm{U}-133$. Stained cells and quantified results are presented, respectively (a and $\mathbf{b})$. Zoomed image of stained EAC cell after $2 \mathrm{~h}$ incubation with $\mathrm{U}-133$. Arrow indicates cell surface (c). 


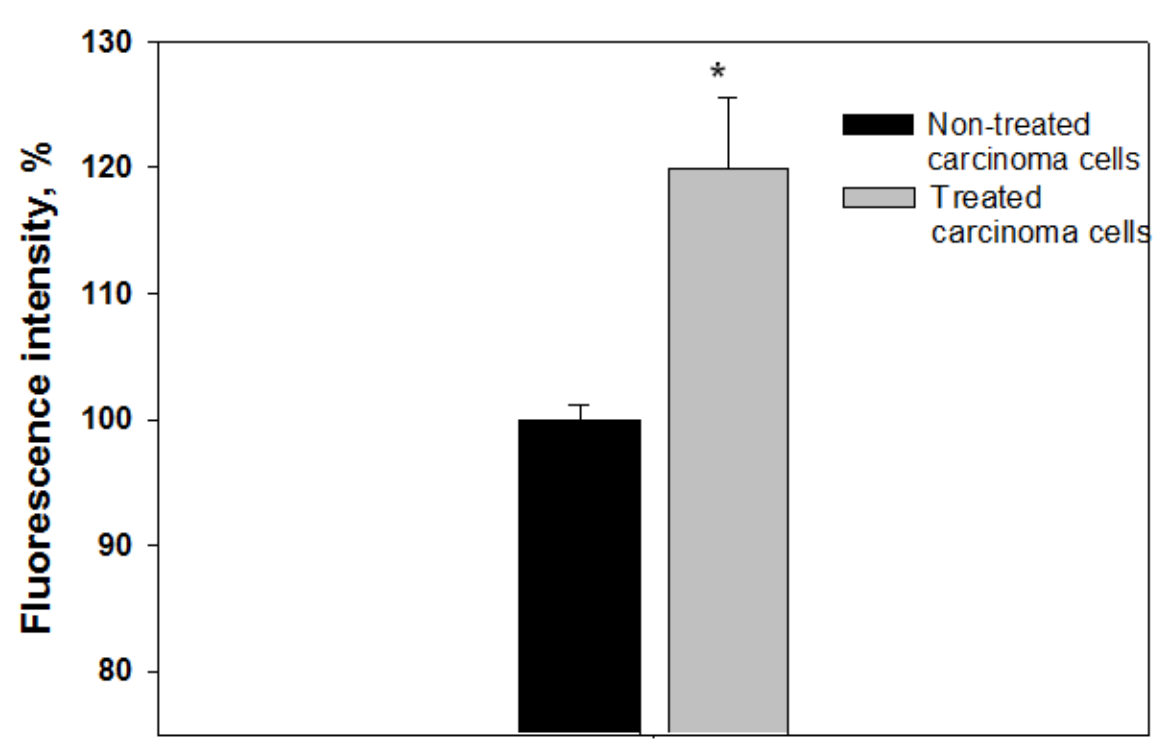

Figure 4: Influence of U-133 on cytotoxic activity of murine splenocytes against EAC cells. EAC cells were incubated with $5 \mu \mathrm{M} U-133$ for $2 \mathrm{~h}$. * $\mathrm{p}<0.05$ compared with non-treated cells.

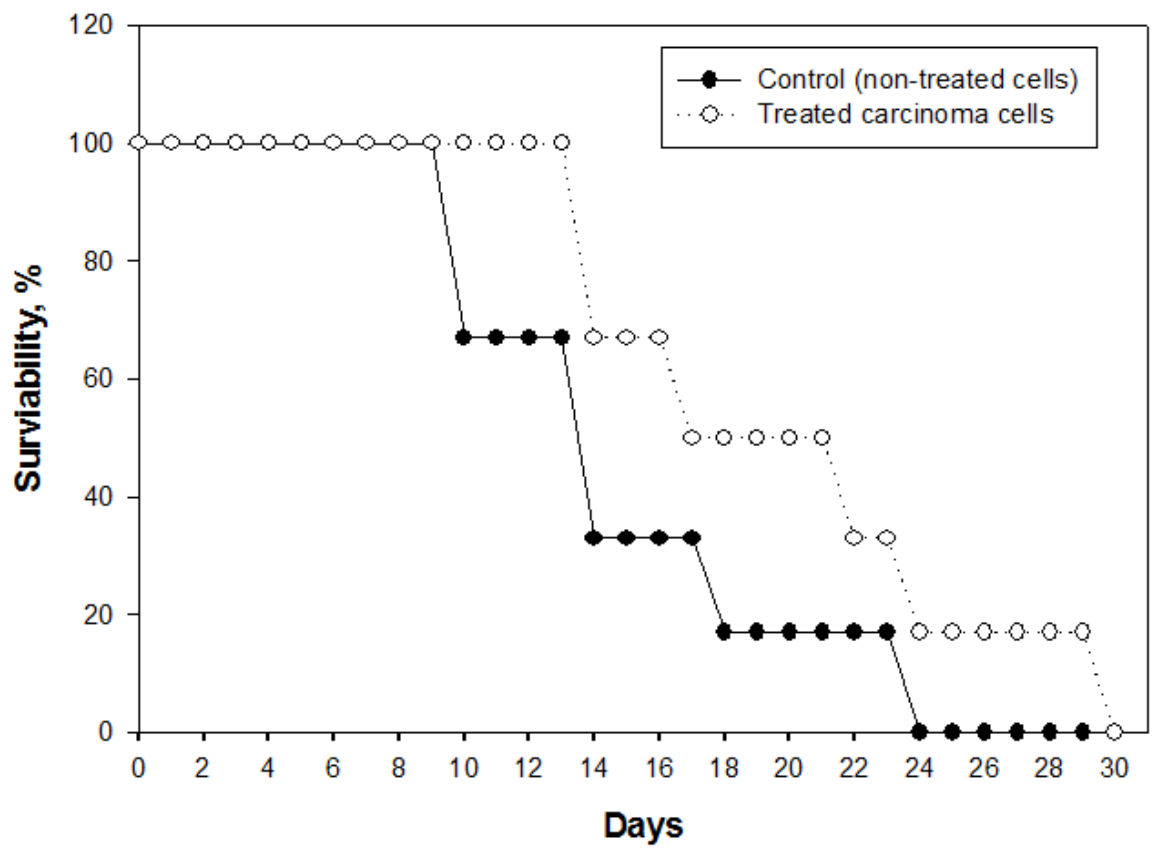

Figure 5: Survival rates of mice with Ehrlich ascites carcinoma. EAC cells were pretreated with $1 \mu \mathrm{M} \mathrm{U}-133$ for $3 \mathrm{~h}$ and then inoculated in to the mice.

resolution MRT. Solid Ehrlich carcinoma growth rate was studied in the in vivo experiments starting on $7^{\text {th }}$ day post tumor inoculation when the tumor knots became detectable. The tumor volume was increased rapidly in mice from control group, and after 3 weeks it was expanded to 10 times (from $0.389 \pm 0.046 \mathrm{~cm}^{3}$ after 7 days to $3.342 \pm 0.168 \mathrm{~cm}^{3}$ after 28 days of tumor inoculation).

It was found that the U-133 application suppressed the solid form of mouse Ehrlich carcinoma growth. The best results concerning reliable delay of the tumor growth were achieved for the group of animals receiving the compound subcutaneously at dosage of $100 \mathrm{mg} / \mathrm{kg}$ every two-three days, seven times in all. Administration of U-133 along with a "curing" scheme resulted in a reliable decrease of the tumor size compared to the control, and the maximal anticancer effect was observed on twenty first day of the experiment. To this time the tumor volume in control group was found to be $2.883 \pm 0.107 \mathrm{~cm}^{3}$, whereas in experimental group the tumor volume was $1.708 \pm 0.270 \mathrm{~cm}^{3}(59.2 \%$ of control). Thus, the delay in tumor growth reached about $41 \%$ on $21^{\text {st }}$ day of the experiment. Mouse Ehrlich solid carcinoma growth rate and 


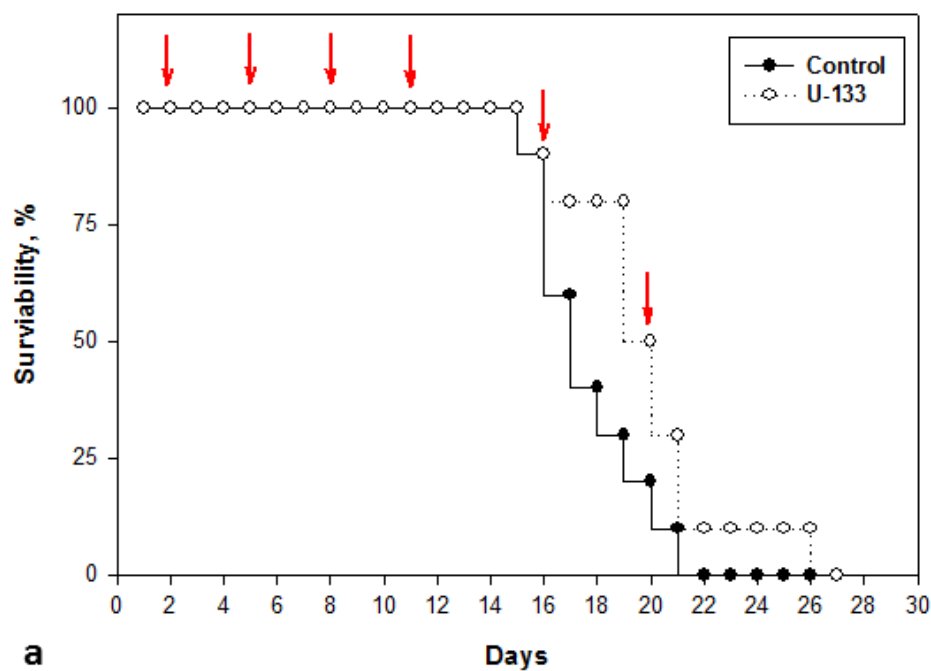

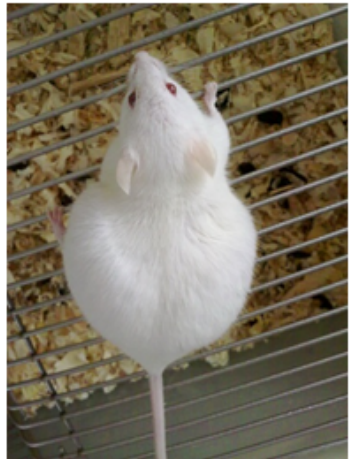

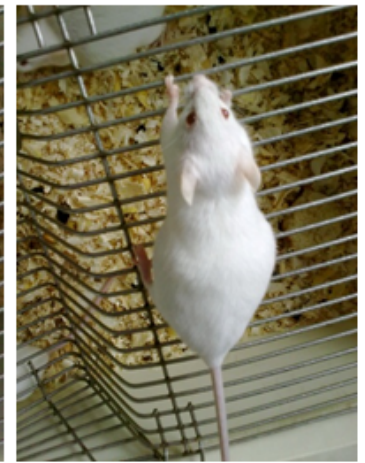

b
C

Figure 6: Survival rates of mice with Ehrlich solid ascites carcinoma. U-133 was administered subcutaneously in dose of $100 \mathrm{mg} / \mathrm{kg}$. Arrow indicates the days of compound administration (a) Representative photograph of tumor-bearing mouse of control group (b) and experimental group received $\mathrm{U}-133$ (c) on $12^{\text {th }}$ day post tumor inoculation.

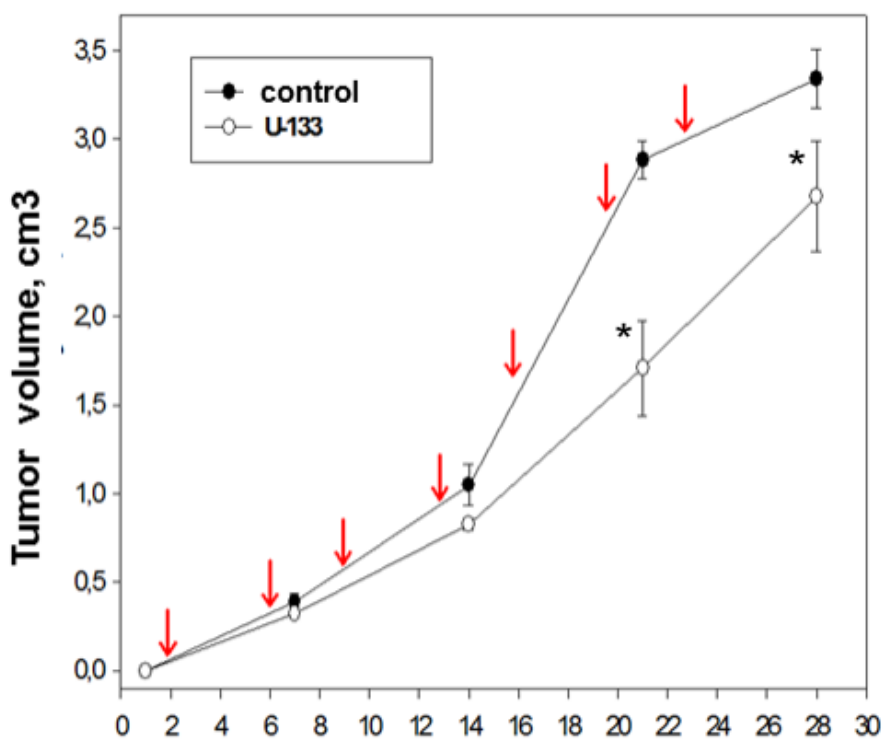

a

\section{Days after inoculation}

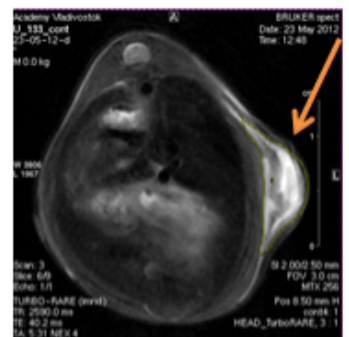

b

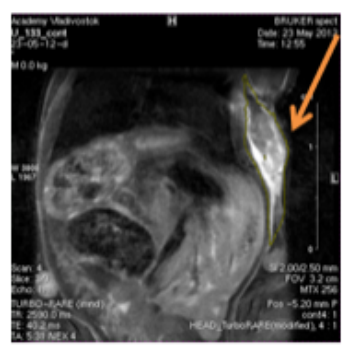

d

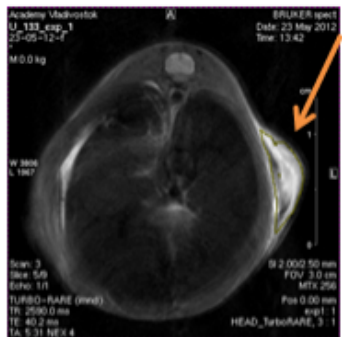

c

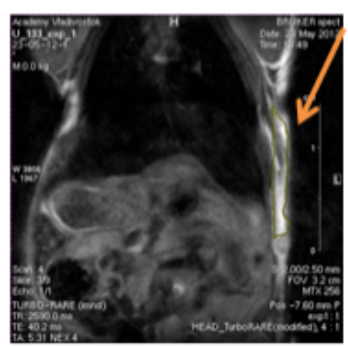

$\mathbf{e}$

Figure 7: U-133 administration reduces Ehrlich carcinoma growth rate. Arrows indicate the days of compound administration (a). Images of mouse tumor knots obtained by MRT scanning at day 21 after tumor inoculation ( $\mathbf{b}-\mathbf{e})$. Axial (b and $\mathbf{c})$ and coronary (d and $\mathbf{e})$ MRT-images, (b and $\mathbf{d})$ control mouse, (c and e) mouse received U-133 therapy. Arrows indicate carcinoma knot localization. Data are shown as $\mathrm{m} \pm \mathrm{sd}$; ${ }^{*} \mathrm{p}<0.05$.

images of mouse tumor knots obtained by MRT scanning at day 21 after tumor inoculation are shown in Figure 7.

In this study we show that U-133, semisynthetic acetylated trisglucosydic echinochrome derivative, induces Hsp70 expression in EAC cells. It was established that Hsp70 expression in cells exposed to $\mathrm{U}-133$ is time-dependent. These results have been confirmed in several independent experiments where the fact of of Hsp70 induction was established with the aid of Hsp70.1 (HSPA1A) promoter-luciferase reporter HeLa cell line, immunoblotting and confocal microscopy.
Previously, we found that both heat shock and the U-133 substance were effective inducers of Hsp70, and the amount of the protein remained high during at least $24 \mathrm{~h}$. The content of Hsp70 in the heattreated cells increased approximately $3 \mathrm{~h}$ earlier and the protein itself remained in the cells for a longer time than after the treatment with $\mathrm{U}-133$ [13].

Hsp70 is known to be Yanus-like protein; the chaperone protects cells from apoptosis by inhibiting lysosomal membrane permeabilization which may be one of the reasons of tumor resistance to chemotherapeutic agents [32,33]. Furthermore, the background 
cytosolic Hsp70 level of cancer cells higher than in normal cells that provides a cell response to such stresses as hypoxia, radiation and chemotherapy [34]. On the other hand the appearance of Hsp70 at the surface of a cancer cell triggers activation of cytotoxic NK cells as proved by the group of Multhoff [19]. We can hypothesize that the NK cell-mediated destruction of tumor can lead to the appearance of Hsp70 complexes with tumor antigen, their incorporation to dendrytic cells, the event leading ultimately to the development of the specific anti-tumor activity represented by $\mathrm{CD}^{+}$and $\mathrm{CD}^{+}$cells [35,36]. Taken together, the experimental data suggest that Hsp70 induction serves to signal the immune system of the presence of an immunologically relevant (dangerous) situation against which an immune reaction should be raised $[19,22,37,38]$.

We have found that the U-133 antitumor activity was observed not only in the case when cancer cells were preincubated with compound in vitro first and then inoculated into mice intraperitoneally, but also in cases of compound's therapeutic subcutaneous administration to animals with pre-grafted solid or ascitic form of Ehrlich carcinoma. In all the above experiments, the antitumor effect was developed as resulted in a longer lifespan of mice and significant inhibition of tumor growth.

We have observed that the Hsp70 chaperone appearance in the cancer cell cytoplasm and membranes under the U-133 influence was accompanied with the significant enhancement of mouse splenocyte cytotoxic properties when they are co-incubated with Ehrlich ascites carcinoma cells. Obviously, the observed antitumor effects of U-133 can be explained by its non-direct influence upon splenocyte cytotoxic properties. It should be noted that the antitumor effect of the U-133 was manifested mainly in the initial stages of tumor development. Pronounced delay in the dynamics of tumor growth was occurred under the influence of the U-133 during the first 12 days of the animal curing. It is possible that the combined experiments to study the antitumor effect of U-133 with a known cytostatic agent (e.g., 5-fluorouracil, cyclophosphamide and doxorubicin) may be the most promising.

\section{Conclusion}

Thus, we have demonstrated that U-133 has a marked antitumor effect in the early stages of mouse Ehrlich carcinoma growth. This effect may be mediated by increased expression of Hsp70 chaperone in tumor cells, its appearance on the cell surface and increase the sensitivity of tumor cells to the cytotoxic effects of immune cells.

\section{Acknowledgements}

We thank Dr. R.I. Morimoto (Northwestern University, Evanston, USA) for providing the stable Hsp70.1 promoter-luciferase reporter HeLa cell line. The studying of Hsp70 location in Ehrlich carcinoma cells by confocal microscopy was supported by Russian Science Foundation (Grant No14-25-00037). The investigation of anticancer activity of U-133 in vivo was supported by International Science and Technology Center (Project No. 4009).

\section{References}

1. Martínez MJA, Benito PB (2005) Biological activity of quinones. Studies in Natural Products Chemistry 303-366.

2. Gordaliza $M(2010)$ Cytotoxic terpene quinones from marine sponges. Mar Drugs 8: 2849-2870.

3. Sperry J, Bachu P, Brimble MA (2008) Pyranonaphthoquinones--isolation, biological activity and synthesis. Nat Prod Rep 25: 376-400.

4. Kharwar RN, Verma VC, Kumar A, Gond SK, Harper JK, et al. (2009) Javanicin, an antibacterial naphthaquinone from an endophytic fungus of neem, Chloridium sp. Curr Microbiol 58: 233-238.

5. Hook I, Mills C, Sheridan H (2014) Bioactive Naphthoquinones from Higher Plants. Amsterdam: Elsevier. Pp. 119-160.

6. Kitagawa RR, Raddi MS, Santos LC, Vilegas W (2004) A new cytotoxic naphthoquinone from Paepalanthus latipes. Chem Pharm Bull (Tokyo) 52: 1487-1488.

7. Ernst-Russell MA, Elix JA, Chai CLL, Willis AC, Hamada N, et al. (1999) Hybocarpone, a novel cytotoxic naphthazarin derivative from mycobiont cultures of the lichen Lecanora hybocarpa. Tetrahedron Letters 40: 6321-6324.

8. Moore RE, Singh H, Scheuer PJ (1966) Isolation of eleven new spinochromes from echinoids of the genus Echinothrix. J Org Chem 31: 3645-3650.

9. Mishchenko NP, Fedoreev SA, Bagirova VL (2003) Histochrome: A new original domestic drug. Pharmaceutical Chemistry Journal 37: 48-52.

10. Lebedev AV, Ivanova MV, Levitsky DO (2005) Echinochrome, a naturally occurring iron chelator and free radical scavenger in artificial and natural membrane systems. Life Sci 76: 863-875.

11. Jeong SH, Kim HK, Song IS, Noh SJ, Marquez J, et al. (2014) Echinochrome a increases mitochondrial mass and function by modulating mitochondrial biogenesis regulatory genes. Mar Drugs 12: 4602-4615.

12. Eremenko EM, Antimonova OI, Shekalova OG, Polonik SG, Margulis BA, et al. (2010) [Novel compounds increasing chaperone Hsp70 expression and their biological activity]. Tsitologiia 52: 235-241.

13. Lazarev VF, Onokhin KV, Antimonova OI, Polonik SG, Guzhova IV, et al (2011) Kinetics of chaperone activity of proteins Hsp70 and Hdj1 in human leukemia u-937 cells after preconditioning with thermal shock or compound u-133. Biochemistry (Mosc) 76: 590-595.

14. Ferrarini M, Heltai S, Zocchi MR, Rugarli C (1992) Unusual expression and localization of heat-shock proteins in human tumor cells. Int J Cancer 51: 613-619.

15. Udono H, Srivastava PK (1994) Comparison of tumor-specific immunogenicities of stress-induced proteins gp96, hsp90, and hsp70. J Immunol 152: 5398-5403.

16. Multhoff G, Botzler C, Wiesnet M, Muller E, Meier T, et al. (1995) A stressinducible $72-\mathrm{kDa}$ heat-shock protein (HSP72) is expressed on the surface of human tumor cells, but not on normal cells. Int J Cancer 61: 272-279.

17. Tamura Y, Tsuboi N, Sato N, Kikuchi K (1993) 70 kDa heat shock cognate protein is a transformation-associated antigen and a possible target for the host's anti-tumor immunity. J Immunol 151: 5516-5524.

18. Hyun JJ, Lee HS, Keum B, Seo YS, Jeen YT, et al. (2013) Expression of heat shock protein 70 modulates the chemoresponsiveness of pancreatic cancer Gut Liver 7: 739-746.

19. Multhoff G (2007) Heat shock protein 70 (Hsp70): membrane location, export and immunological relevance. Methods 43: 229-237.

20. Zhang $Y$, Zheng $L$ (2013) Tumor immunotherapy based on tumor-derived heat shock proteins (Review). Oncol Lett 6: 1543-1549.

21. Zhang H, Liu R, Huang W (2007) A 14-mer peptide from HSP70 protein is the critical epitope which enhances NK activity against tumor cells in vivo. Immunol Invest 36: 233-246.

22. Botzler C, Issels R, Multhoff G (1996) Heat-shock protein 72 cell-surface expression on human lung carcinoma cells in associated with an increased sensitivity to lysis mediated by adherent natural killer cells. Cancer Immunol Immunother 43: 226-233.

23. Gehrmann M, Pfister K, Hutzler P, Gastpar R, Margulis B, et al. (2002) Effects of antineoplastic agents on cytoplasmic and membrane-bound heat shock protein 70 (Hsp70) levels. Biol Chem 383: 1715-1725.

24. Chen S, Sun L, Koya K, Tatsuta N, Xia Z, et al. (2013) Syntheses and antitumor activities of N',N'3-dialkyl-N',N'3-di-(alkylcarbonothioyl) malonohydrazide: the discovery of elesclomol. Bioorganic \& medicinal chemistry letters 23: 50705076 .

25. Mischenko NP, Fedoreyev SA, Pokhilo ND, Anufriev VP, Denisenko VA, et al (2005) Echinamines $A$ and $B$, first aminated hydroxynaphthazarins from the sea urchin Scaphechinus mirabilis. J Nat Prod 68: 1390-1393.

26. Polonik SG, Tolkach AM, Uvarova NI (1994) Glicozilation of echinochrome and similar hydroxynaphthazarines by orthoether method. Zh Org Khim 30: 260-265.

27. Carmichael J, DeGraff WG, Gazdar AF, Minna JD, Mitchell JB (1987) Evaluation of a tetrazolium-based semiautomated colorimetric assay: assessment of radiosensitivity. Cancer Res 47: 943-946.

28. Westerheide SD, Bosman JD, Mbadugha BN, Kawahara TL, Matsumoto G, et al. (2004) Celastrols as inducers of the heat shock response and cytoprotection. J Biol Chem 279: 56053-56060. 
Citation: Yurchenko EA, Menchinskaya ES, Polonik SG, Agafonova IG, Guzhova IV, et al. (2015) Hsp70 Induction and Anticancer Activity of U-133, the Acetylated Trisglucosydic Derivative of Echinochrome. Med chem 5: 263-271. doi: 10.4172/2161-0444.1000274

29. Dewan MZ, Takada M, Terunuma H, Deng X, Ahmed S, et al. (2009) Natural killer activity of peripheral-blood mononuclear cells in breast cancer patients. Biomed Pharmacother 63: 703-706.

30. Deng X, Terunuma H, Nieda M, Xiao W, Nicol A (2012) Synergistic cytotoxicity of ex vivo expanded natural killer cells in combination with monoclonal antibody drugs against cancer cells. Int Immunopharmacol 14: 593-605.

31. Shevtsov MA, Komarova EY, Meshalkina DA, Bychkova NV, Aksenov ND, et al. (2014) Exogenously delivered heat shock protein 70 displaces its endogenous analogue and sensitizes.

32. Nylandsted J, Rohde M, Brand K, Bastholm L, Elling F, et al. (2000) Selective depletion of heat shock protein 70 (Hsp70) activates a tumor-specific death program that is independent of caspases and bypasses Bcl-2. Proc Natl Acad Sci U S A 97: 7871-7876.

33. Nylandsted J, Jaattela M, Hoffmann EK, Pedersen SF (2004) Heat shock protein 70 inhibits shrinkage-induced programmed cell death via mechanisms independent of effects on cell volume-regulatory membrane transport proteins. Pflugers Arch 449: 175-185.
34. Multhoff G, Hightower LE (2011) Distinguishing integral and receptor-bound heat shock protein 70 (Hsp70) on the cell surface by Hsp70-specific antibodies. Cell Stress Chaperones 16: 251-255.

35. Guzhova IV, Shevtsov MA, Abkin SV, Pankratova KM, Margulis BA (2013) Intracellular and extracellular Hsp70 chaperone as a target for cancer therapy. Int J Hyperthermia 29: 399-408.

36. Shevtsov MA, Pozdnyakov AV, Mikhrina AL, Yakovleva LY, Nikolaev BP, et al (2014) Effective immunotherapy of rat glioblastoma with prolonged intratumoral delivery of exogenous heat shock protein Hsp70. Int J Cancer 135: 2118-2128.

37. Todryk S, Melcher AA, Hardwick N, Linardakis E, Bateman A, et al. (1999) Heat shock protein 70 induced during tumor cell killing induces Th1 cytokines and targets immature dendritic cell precursors to enhance antigen uptake. $J$ Immunol 163: 1398-1408.

38. Gehrmann M, Radons J, Molls M, Multhoff G (2008) The therapeutic implications of clinically applied modifiers of heat shock protein 70 (Hsp70) expression by tumor cells. Cell Stress Chaperones 13: 1-10. 